Original Research Paper

\title{
Scrutiny of Relationship between E-Banking Information Quality Dimensions and Customer Satisfaction
}

\author{
Mohannad Moufeed Ayyash \\ Department of Management Information Systems, \\ Al-Baha Private College of Science, Al-Baha, Kingdom of Saudi Arabia
}

Article history

Received: $12-10-2016$

Revised: $18-02-2017$

Accepted: 25-04-2017

Corresponding Author: Mohannad Moufeed Ayyash Department of Management Information Systems, Al-Baha Private College of Science, AlBaha, Kingdom of Saudi Arabia

Email: mohannad.ayyash@gmail.com

\begin{abstract}
Poor information quality can have a significant negative effect on the success of an organization. This study investigated the relationship between information quality's dimensions, namely accuracy, completeness, timeliness and relevancy, on the satisfaction of customers towards E-banking services in Palestine's banking sector. It also studied the relationship between the intent to use E-banking services and customer satisfaction. The study implemented a quantitative method for data collection using a questionnaire survey. The results revealed that the accuracy, completeness, timeliness and relevancy of information had a positive effect on customer satisfaction towards E-banking services. Consequently, customer satisfaction affects the intention to utilize such services. The study also offered limitations, conclusions and recommendations for further studies in the future.
\end{abstract}

Keywords: Dimensions, Customer Satisfaction, E-banking, Information Quality Information Systems Success Model, Palestine

\section{Introduction}

The demand of small-medium and large multinational organizations for Information Technology (IT) has grown in the past couple of decades (Tarhini et al., 2016). Because of IT's global progress, there is a greater need for organizations to have the ability to leverage these techniques in order to make sure that they achieve progress and development (Ayyash et al., 2012). In the context of banking, it has been observed that customers are shifting more from traditional to electronic banking methods via Electronic banking (E-banking).

Assessing information systems is a vital aspect that can help determine their efficacy within organizations (Manchanda and Mukherjee, 2014; Davis and Jackson, 2005). According to Ramayah et al. (2010), an information system that provides high quality content will improve user engagement with the services provided.

Information is at the center of the current evolving world (Nurse et al., 2011). The importance and value of information cannot be questioned. According to Munir (2015), information quality is one the E-banking industry's basic quality attributes.

Recently, it has been noted that there has been considerable significant rise in the amount of information that organizations can access, along with their dependency on such information (Baskarada et al., 2006; Ballou et al., 2003). In 2008, Gartner Research reported that organizations that cannot manage their information will have a hard time securing their niche within the business environment (Logan and Newman, 2006). Furthermore, the Gartner survey offered evidence that signified that most of the providers of financial services have experienced issues related to their decision support and operational initiatives. These issues are a result of information with sub-optimal quality $\mathrm{x}$ (Friedman et al., 2004). It was further stated that about $40 \%$ of the firms that implemented a customer relationship management strategy were unaware of the issues in information quality within their market surroundings (Knox, 2004).

Buzzacchi et al. (1995) stated that both relatively standardized and immaterial financial services were greatly affected by innovations in information technology. Thus, financial services are considered one of the top areas where new information economies are expected to emerge (Dewan et al., 2000). In recent years, E-banking, a distribution channel often used by financial services firms, has increased in significance since its inception during the mid-1990s (Allen et al., 2001).

Chavan (2013) describes E-banking as an Internet portal that allows customers to access various banking 
services. The Internet has become an important part of the daily lives of people. It has even changed consumer behavior in various ways. For example, in order to complete certain tasks, banks used to require consumers to visit a bank branch to perform financial transactions (Unyathanakorn and Rompho, 2014).

Given this background, E-banking in virtually any country depends on several factors, including new online banking characteristics, successful Internet access, increase in the amount of households that have Internet and regulatory and legal frameworks. Furthermore, Ebanking has had a large impact on how customers use banking services (Al Haliq and Al Muhirat, 2016). Given this context and compared to the manual banking system, E-banking may be able to offer more dependable and timely customer services to meet customer satisfaction (Nupur, 2010).

However, when it comes to Internet banking, providers are faced with the major issue that most of their customers are not motivated to utilize the provided Internet banking services (Ling et al., 2016). This is often attributed to the fact that customers are not yet satisfied with the services being provided by Internet banking. Customer satisfaction is an important factor that allows banks to maintain their competitive advantages.

In the Palestinian context, it is believed that the country can develop E-banking services easily. Nevertheless, a study conducted by Wungwanitchakorn (2002) revealed that in most developing nations, E-banking are still in their infancy. Therefore, in order for banks to leverage the benefits of E-banking, they need to determine how their potential customers perceive their services. They also need to identify the factors that affect the level of customer satisfaction, such as the quality of information provided by E-banking and their continuous dealings with the services. As a matter of fact, customer satisfaction is an important marketing element, given the relationship between overall service performance and satisfaction (Truch, 2006). Because banks have invested billions of dollars in internet infrastructure, customer satisfaction is increasingly becoming a core success factor in Ebanking (Bauer et al., 2005). Nonetheless, low customer satisfaction is still one of main challenges when it comes to developing E-banking services in the context of the Palestinian banking sector.

Several studies have examined the quality of the information that information systems generate. However, because web quality and its measurement is complex, it is believed to have multidimensional aspects that have not been investigated by prior studies (Aladwani and Palvia, 2002). As such, the main concern during the evaluation of information systems is how to determine the criteria for quality
(Buyukozkan et al., 2007). In the E-banking context, high quality information systems also improve the customers' intention to adopt the services (Ayyash, 2015). Therefore, it is vital to have good information quality in order to improve the satisfaction of customers towards the E-banking services being provided.

The current research has its basis in the need to study the relationship between the quality of the information dimensions and customer satisfaction. Customer satisfaction contributes to the improvement of the adoption rate of E-banking services in Palestine. The findings of the research are expected to have valuable contributions to the development of appropriate strategies within the banking sector. It is also expected to help customer satisfaction. The aim of the study was to minimize the literature gap by conducting empirical examinations of the information quality dimensions that affect customer satisfaction towards the E-banking services in Palestine. It is expected that the results will reveal how information quality dimensions influence customer satisfaction towards E-banking services. Moreover, it will reveal the influence of the latter on the intention of customers to use the services.

Furthermore, the study's findings are expected to be considered as bases for future developments of Ebanking strategies that are more effective in promoting and achieving customer satisfaction. The study's best contribution was its investigation of the information quality dimensions that affect customer satisfaction in the Palestinian banking sector's Ebanking services.

\section{Theoretical Background}

\section{Information System Success Model}

The DeLone and McLean Information System Success Model has been theoretically and empirically evaluated by several studies. Researchers have also tested applicability to various sectors. Furthermore, it has achieved acceptance among researchers (Manchanda and Mukherjee, 2014).

DeLone and McLean (1992) proposed an information system success model that has the capacity determine an information system's level of success. According to Sang and Lee (2009), several research works have validated the IS success model of DeLone and McLean (Rai et al., 2002; Seddon and Min-Yen, 1994). Moreover, they have stated that this model has also been utilized in consumer e-commerce analysis (Delone and Mclean, 2004; Molla and Licker, 2001). DeLone and McLean (1992) came up with this model in order to determine the success of IS and for it to even act as a basis for future research. The authors developed six dimensions that they used to measure the system's success, namely use, system quality, user satisfaction, 
organizational impact, information quality and individual impact.

It has been noted that the quality of the system and information has an influence on the use and user satisfaction. They exert effects both separately and together. Others can be affected by the intention to use and user satisfaction, while directly affecting individual impact. In turn, the organizational impact is affected by the individual impact (DeLone and McLean, 1992).

This model (DeLone and McLean, 1992) is often called the original model. However, this model is still not complete. Delone and McLean (2003) updated their model to include the research studies that were performed between 1992 and 2003. The updated model has the following enhancements: The addition of 'service quality' to reflect the importance of service in ensuring successful e-commerce systems, addition of 'intention to use' as a measure of user attitude and considering it as an alternative 'use' measurement and conflating 'individual impact' and 'organizational impact' in a 'more parsimonious' net benefits 'construct'.

DeLone and McLean's model for information systems has found wide uses in numerous studies (Ramdan et al., 2014; Romi, 2013; Khayun et al., 2012). The DeLone and McLean model has been used by the banking sector to carry out empirical studies (Vanniarajan, 2009; Hussein, 2009; Aburas et al., 2013; Mashhour, 2008). Most of these studies focused on electronic banking (Olatokun and Owoeye, 2012; Okechi and Kepeghom, 2013; Andoh-Baidoo et al., 2010; Zhu and Lin, 2010).

As such, the DeLone and McLean (2003) model was adopted in this present study. Information quality was considered a factor that influences user satisfaction towards E-banking services in the context of Palestine. Moreover, literature by (Chau and $\mathrm{Hu}, 2001$ ), (Venkatesh et al., 2003) indicated that the intention to use can be seen as an important predictor of the actual use of the system.

\section{Information Quality Dimensions}

The banking sector has been using information systems widely. These systems are very suitable since banking organizations are intrinsically information intensive. E-banking offers banks the opportunity to provide services that are distinct from traditional banks, including the provision of financial information services, online loan applications, investment products (e.g., bonds purchasing) and other financial services (e.g., purchasing car or life insurance). Moreover, ebanking can provide third-party services (e.g., online payments for taxes and bills) and other products (Jovovic et al., 2016).

Therefore, high quality Information Systems (IS) are more useful in convincing users and improving their intention to utilize the provided services (Ramayah et al., 2010). According to Munir (2015), one of the basic attributes of E-banking quality is information quality. Thus, achieving information quality is vital in improving user satisfaction towards the E-banking services being offered. Thus, the quality of information provided by IS is a vital factor in convincing customers of the usefulness of the system (Chuan-Chuan Lin and Lu, 2000).

According to DeLone and McLean (1992), information quality is a measure of the information system's output. It can also be defined as the measure of the information that is produced by the system (Jennex et al., 1998; Maes and Poels, 2006). According to the model, information quality is the most important factor that determines system use and user satisfaction. Ultimately, it will lead to regular adoption (Wang and Liao, 2008; Wangpipatwong et al., 2005). Empirical studies have proven that information quality have strong associations with system use (Rai et al., 2002), particularly in the context of E-commerce systems (Molla and Licker, 2001).

According to DeLone and McLean (2004), relevance, completeness, currency, accuracy and dynamic content are just some of the characteristics that are related to desirable content. It is generally accepted that the development of a measure for information quality should have its basis in the kind of information system that is under study (Wixom and Todd, 2005). This proposed model of this study follows the Delone and McLean information system's success taxonomy. It also conceptualizes the quality of information from E-banking as the desired output quality from E-banking services.

As previously stated, information quality is considered as the measure of the system's output. This is why users often evaluate the value of information in the context of the characteristics that they require. According to literature, some examples of the dimensions of information quality include reputation, believability, interpretability, completeness, valueadded, reliability, objectivity, price, accuracy, timeliness, latency, verifiability, security, availability and response time (Naumann and Rolker, 2000). Hussein et al. (2007) also stated that information quality includes the accurate, complete, organized, comprehensible and timely information that the website of the system supplies.

A study by Ayyash (2015) revealed that in the IS field, the most commonly used information quality dimensions are accuracy, relevancy, timeliness and completeness of information. Therefore, given their high frequencies, this study has chosen them as representatives of the information quality dimensions. These dimensions were used to evaluate the quality of information provided by the E-banking services 
and assess the satisfaction of customers in the Palestinian context.

\section{Customer Satisfaction and Intention to Use E- Banking Services}

For the past two decades, customer satisfaction has been considered as a strategically valuable aspect for numerous companies (Wang and Pho, 2009). For example, customer satisfaction is considered by the service industry as one of the most important precursors of positive outcomes, including the continued intent to utilize a particular service (Lee et al., 2015). Al-Tit (2015) found out that customer satisfaction is positively affected by service quality and thus suggested that such satisfaction leads to customer retention. Customer satisfaction measures the extent by which the product or service of a firm meets customer expectations (Saleem and Rashid, 2011). Moreover, this concept is considered an important factor in the intention to adopt new technology (Negasha et al., 2003; Yoon et al., 1995). Banks need to make themselves different because if customers only see little to no difference in the provided services, they are more likely to consider new offers as being the similar or even the same to the services that are provided by their competitors.

E-service quality is a vital part of Internet banking and banks since it affects customer satisfaction (Ling et al., 2016). Furthermore, information quality is the main factor that determines the use of the system and user satisfaction, the latter of which ultimately results to regular adoption (Wangpipatwong et al. 2005; Wang and Liao 2008). Therefore, customers with higher satisfaction levels are more likely to use the same service compared to other customers. According to Delone and McLean (2003), information quality can be seen as a measure of the output of the system. Thus, users normally evaluate the value of the information based on the qualities they desire, such as accuracy, completeness and timeliness. In this study, satisfaction is referred to as customer satisfaction towards online banking services, particularly the characteristics of the information generated by Palestinian E-banking websites.

\section{Research Model}

In previous empirical studies focused on E-commerce systems, it has been revealed that the use of the system is related to information quality. Nevertheless, Ayyash (2015) has stated that literature has still not examined the subject of information quality adequately.

E-banking channels are an important interface between the bank and the bank's customers (Stamoulis et al., 2002). Thus, the utilization of these channels allows customers to conduct electronic transactions with the bank's computer network (Jayachandran et al., 2005). There is therefore a need to examine the system's information quality along with its effect on intention to use and customer satisfaction. These factors are all needed for the successful conduct of E-banking practices.

Studies that examined the reality of information systems have emphasized how important it is to ensure the quality of the information that is being provided by the systems. The goal is for it to help improve customer satisfaction. As such, several information quality frameworks have been developed and proposed throughout the years by numerous researchers in various fields (e.g., Bailey and Pearson, 1983; Shanks and Corbitt, 1999; Delone and McLean, 2003; Dedeke, 2000; Hussein et al., 2007; Leung, 2001; Katerattanakul and Siau, 1999; Eppler and Muenzenmayer, 2002; Kahn et al., 2002; Stvilia et al., 2005). Although these prior studies provide similar information quality predictors, very few of them have focused on obtaining dimensions of information quality that influence customer satisfaction in Palestinian E-banking services based on the model of DeLone and McLean for information systems success (Ayyash, 2015).

Thus, in order to address the need for more studies that focus on information quality dimensions and how they affect customer satisfaction towards Palestinian Ebanking services, this research aimed to find answers to the following major research question: What relationships exist between the dimensions of information quality and customer satisfaction and how does the latter affect the intention to use E-banking services? To further narrow down the question, it was sub-divided into the following:

- What relationship exists between customer satisfaction and information accuracy?

- What relationship exists between customer satisfaction and information timeliness?

- What relationship exists between customer satisfaction and information completeness?

- What relationship exists between the intention to use and customer satisfaction?

Because the primary aim of this study was to examine the relationships between customer satisfaction, the intention to use and information quality dimensions, a research model that was made up of DeLone and McLean's (2003) IS success model was developed (Fig. 1) (Ayyash, 2015).

Given this study model, five hypotheses were formulated to test and determine the relationship level between the variables to determine if various hypotheses should be accepted or rejected. 


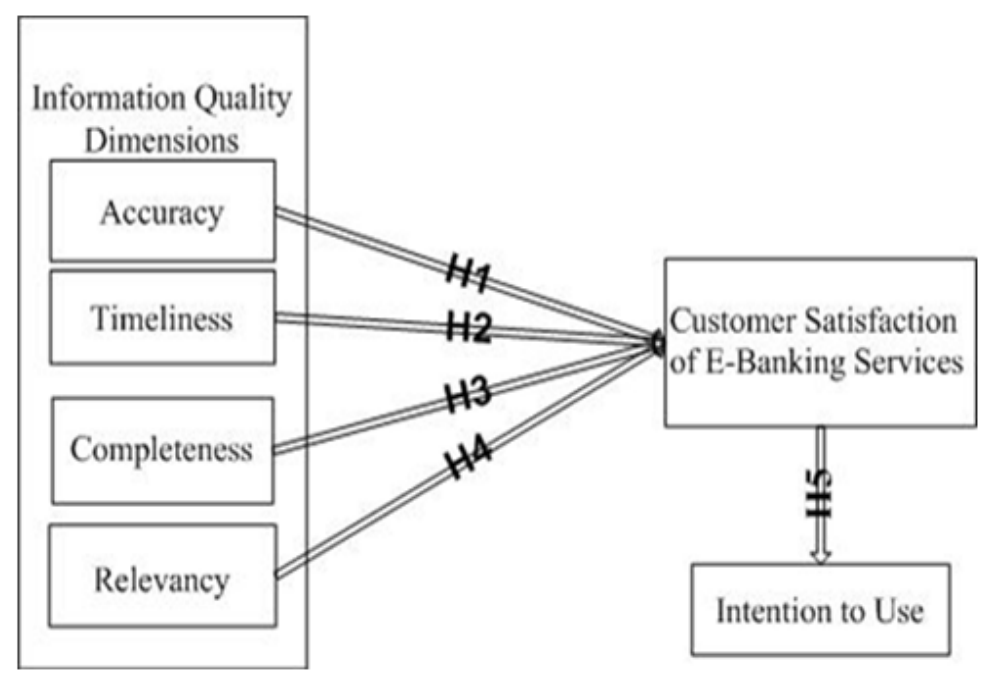

Fig 1. Research model (Ayyash, 2015)

\section{Research Methodology}

\section{Questionnaire, Measurements and Data Analysis}

The study made use of a questionnaire survey that was made up of close-ended questions that offered the respondents a consistent reference structure for the answers. A 5-point Likert scale was used to measure the questionnaire items. Data about the research constructs were collected using scales that started from 1 or strongly disagree to 5 or strongly agree. Furthermore, 3 was neutral. The scales' content validity was ensured by choosing items that were reflective of the constructs' concepts and as confirmed by previous studies. However, they were also modified to suit the context of E-banking. The study involved three Palestinian banks that were randomly chosen. The sample respondents all possessed knowledge on banking services and all owned personal bank accounts. A total of 108 questionnaires in all were distributed, answered and retrieved.

Majority of the respondents (66.7\%) were males and the rest were females. Most of the subjects also belonged to the 30-40 age range. Furthermore, most of them had been using the Internet for 3-10 years (48.1\%), which is an indication of their experience in utilizing online services. Majority of the respondents possessed bachelor degrees $(67 \%)$ or even had higher levels of education.

The study used three information accuracy scale items that were based on the scale by Wixom and Todd (2005). Moreover, six information relevancy scale items were taken from Lee et al. (2002) and three information timeliness scale items were obtained from $\mathrm{Su}$ and Jin (2006). Additionally, five customer satisfaction scale items were obtained from Abu-Dalbouh (2012) and five intentions to use scale items were taken from Carter and Bélanger (2005).

Two different tests were used to validate the hypotheses, multiple regression and linear regression tests. A multiple regression analysis was used to examine the relationship between the customer satisfaction towards E-banking services and independent variables since they were both viewed as having equal importance. Subsequently, the researchers used a simple test to study the relationship between the intention to use E-banking services and customer satisfaction.

The current study explored the relationships between the dimensions of information quality, customer satisfaction towards E-banking services and the customers' intention to utilize e-banking services. These relationships were studied by using descriptive statistics and factor analysis. The measurement scale's validity was confirmed through the conduct of an exploratory factor analysis. Meanwhile, the influence exerted by the four information quality dimensions (i.e., timeliness, accuracy, completeness and relevance) was tested using regression analysis.

\section{Tests for Reliability and Validity of the Measures}

A literature review was used to confirm the study's content validity, while a factor analysis was used to confirm its construct validity. All the study's items obtained factor loading values that were more than +0.40 . This signifies that every item had a significant correlation to its respective factors and that a single set of items was capable of measuring a single concept. Table 1 shows the validity of the measurements. 
Table 1. Measurements of the study

\begin{tabular}{|c|c|c|c|}
\hline Construct & Item & Loading & St. Error. \\
\hline \multirow[t]{3}{*}{ Information Accuracy } & Information Accuracy 1 & 0.864 & 0.517 \\
\hline & Information Accuracy 2 & 0.904 & 0.508 \\
\hline & Information Accuracy 3 & 0.899 & 0.532 \\
\hline \multirow[t]{3}{*}{ Information Timelines } & Information Timelines 1 & 0.840 & 0.501 \\
\hline & Information Timelines 2 & 0.889 & 0.518 \\
\hline & Information Timelines 3 & 0.893 & 0.567 \\
\hline \multirow[t]{3}{*}{ Information Completeness } & Information Completeness 1 & 0.906 & 0.500 \\
\hline & Information Completeness 2 & 0.883 & 0.497 \\
\hline & Information Completeness 3 & 0.865 & 0.563 \\
\hline \multirow[t]{6}{*}{ Information Relevancy } & Information Relevancy 1 & 0.425 & 0.490 \\
\hline & Information Relevancy 2 & 0.648 & 0.564 \\
\hline & Information Relevancy 3 & 0.699 & 0.573 \\
\hline & Information Relevancy 4 & 0.800 & 0.639 \\
\hline & Information Relevancy 5 & 0.735 & 0.564 \\
\hline & Information Relevancy 6 & 0.718 & 0.627 \\
\hline \multirow[t]{5}{*}{ Customer Satisfaction } & Customer Satisfaction 1 & 0.608 & 0.723 \\
\hline & Customer Satisfaction 2 & 0.709 & 0.798 \\
\hline & Customer Satisfaction 3 & 0.772 & 0.690 \\
\hline & Customer Satisfaction 4 & 0.757 & 0.652 \\
\hline & Customer Satisfaction 5 & 0.639 & 0.662 \\
\hline \multirow[t]{5}{*}{ Intention to use } & Intention to Use 1 & 0.967 & 0.452 \\
\hline & Intention to Use 2 & 0.537 & 0.527 \\
\hline & Intention to Use 3 & 0.696 & 0.709 \\
\hline & Intention to Use 4 & 0.876 & 0.510 \\
\hline & Intention to Use 5 & 0.459 & 0.879 \\
\hline
\end{tabular}

Table 2. Cronbach's Alpha values for reliability test

\begin{tabular}{lll}
\hline Section of Questionnaire & Measurement tool & Cronbach's alpha coefficient value \\
\hline B & Information Accuracy & 0.867 \\
C & Information Timelines & 0.845 \\
D & Information Completeness & 0.859 \\
E & Information Relevancy & 0.765 \\
F & Customer Satisfaction & 0.734 \\
G & Intention to Use & 0.853 \\
& Overall Reliability (25 items) & 0.824 \\
\hline
\end{tabular}

The internal consistency method was used to evaluate reliability of the measurement tools. A reliability test was conducted for the survey items found in Sections B, C, D, E, F and G. Table 2 shows the results of the reliability test for each section of the questionnaire.

Because each measurement tool has an acceptable Cronbach's alpha value, no item was deleted. This means that all the items achieved good internal consistency.

\section{Results}

Validation of the hypotheses was done using two different tests - linear regression and multiple regression. The relationship of the independent variables with the customer satisfaction towards E-banking services was studied using multiple regression analysis.

The following hypotheses were evaluated during the initial regression tests:
H1: Information accuracy will have a positive effect on customer satisfaction towards E-banking services.

H2: Information timeliness will have a positive effect on customer satisfaction towards E-banking services.

H3: Information completeness will have a positive effect on customer satisfaction towards E-banking services.

H4: Information relevancy will have a positive effect on customer satisfaction towards E-banking services.

For the four hypotheses, the standard mode was used to run the multiple regression test, with customer satisfaction towards E-banking services representing the dependent variable. The information quality dimensions of accuracy, completeness, timeliness and relevancy were the independent variables. Table 3 shows the results of the analysis. As seen in the table, information accuracy has a significant relationship 
with customer satisfaction towards E-banking services at $(\beta=0.256, \mathrm{t}=2.576, \mathrm{p}<0.001)$. Furthermore, information timeliness has a significant relationship to customer satisfaction towards E-banking services at ( $\beta$ $=0.160, \mathrm{t}=1.888, \mathrm{p}<0.001)$, information completeness had a significant relationship to customer satisfaction towards E-banking services at $(\beta$ $=0.083, \mathrm{t}=1.087, \mathrm{p}<0.001)$ and information relevancy had a significant relationship to customer satisfaction towards E-banking services at $(\beta=0.461$, $\mathrm{t}=3.951, \mathrm{p}<0.001)$.

Table 3 also shows the statistical significance $\left(\mathrm{R}^{2}\right)$ with $F=146.536$ and $p<0.001$, given how the four independent variables had a positive correlation to customer satisfaction towards E-banking services $(\mathrm{R}=$ 0.922 ). Thus, an $\mathrm{R}$-square value of 0.851 signifies that the variables could account for over $85.1 \%$ of the variance observed in customer satisfaction towards Ebanking services. The standard estimated error had a value of 0.15122 . This signifies that all the independent variables had a significant effect on customer satisfaction towards E-banking services. Hence, the findings supported the hypotheses.

The next step was to perform a simple regression analysis between the intention to use e-banking services and customer satisfaction towards E-banking services based on the following hypothesis:

H5: Customer satisfaction towards E-banking services will have a positive effect on the intention to use.

The results gave an $\mathrm{R}^{2}$ value of 0.359 , signifying that customer satisfaction towards E-banking services accounted for $35.9 \%$ of the variance observed in the intention to use. The estimated standard error value was at 0.30577 . The results also showed that customer satisfaction towards E-banking services had a significant relationship with the intention to use at $(\beta$ $=0.599, \mathrm{t}=7.701, \mathrm{p}<0.001)$ (Table 4 for results). The value of the significance of customer satisfaction towards E-banking services did not go over 0.05, which is an indication that there was a positive significant relationship between the two variables. A statistically high significant $\mathrm{R}^{2}$ was obtained at $\mathrm{F}=$ 59.313 and $\mathrm{p}<0.001$. This supports hypothesis (H5).

In summary, the results supported the proposed hypotheses that information quality's dimensions (i.e., accuracy, completeness, timeliness and relevancy) had a positive influence on customer satisfaction towards E-banking services. Furthermore, the results supported the proposed hypothesis that customer satisfaction towards E-banking services was positively related to the intention to use.
Table 3. Regression results from information quality dimensions and customer satisfaction

\begin{tabular}{ll}
\hline Model & Standardized beta coefficients \\
\hline Information Accuracy & 0.256 \\
Information Timeliness & 0.160 \\
Information Completeness & 0.083 \\
Information Relevancy & 0.461 \\
$\mathrm{R}^{2}$ & 0.851 \\
Adjusted $\mathrm{R}^{2}$ & 0.845 \\
F value & 146.536 \\
\hline
\end{tabular}

Table 4. Regression results on customer satisfaction towards Ebanking services and the intention to use

\begin{tabular}{ll}
\hline Model & Standardized coefficients beta \\
\hline Customer satisfaction towards & 0.599 \\
E-Banking services & \\
$\mathrm{R}^{2}$ & 0.359 \\
Adjusted $\mathrm{R}^{2}$ & 0.353 \\
F value & 59.313 \\
\hline
\end{tabular}

\section{Discussion}

This study mainly aimed to examine the relationship between the information quality dimensions of accuracy, completeness, timeliness and relevancy and the satisfaction of customers towards E-banking services. This study's secondary aim was to investigate the relationship between the intention to use E-banking services and customer satisfaction. A thorough review of the literature revealed that very few studies had chosen to focus on the information quality dimensions, especially those that affect customer satisfaction towards E-banking services. Ayyash (2015) has even argued that studies that aimed to determine the information quality dimensions that affect customer satisfaction in the Palestinian context of E-banking services were few and very seldom. Hence, the researcher aimed to address this issue by pursuing this research. The results will potentially help policy makers within the banking industry aim their focus on the information quality dimensions that significantly influence customer satisfaction. The following sections will further explain the detailed findings and their expected contributions.

\section{Information Quality Dimensions and Customer Satisfaction towards E-banking Services}

Several studies found in current literature have studied the quality of information in terms of egovernment and e-commerce. Wangpipatwong et al. (2005), for example, was able to prove the important influence of information quality on the utilization of egovernment websites. Moreover, David et al. (2004) stated that an important determinant in the inclination towards the utilization of e-government is information quality. On the other hand, Almahamid et al. (2010) discovered that there exists a positive relationship 
between the intention to use e-government services and information quality. Similarly, Ayyash et al. (2013) also stated that perceived information quality positively has a significant impact on the user's trust in the initiative of adopting e-government in public organizations. However, very few researches have studied the effect of information quality dimensions on the satisfaction of customers towards the Palestinian Ebanking services sector.

Moreover, given the lack of physical interaction with the items in an online environment, the customers' online purchase decisions are affected by information quality (Wixom and Todd, 2005; Kim and Lennon, 2008). Setia et al. (2013) stated that in India's banking industry, customer service capabilities are positively related to information quality. However, in current literature about information quality, the emphasis has always been on the character differences among domains (marketing, information systems, accounting, etc.) (Harrison, 2016). For example, in terms of information systems, the issue of information quality mainly determines the construct as successful technology's determinant (e.g., DeLone and McLean, 1992). A related study by O'Reilly (1982) emphasized distinct attributes like accessibility, while a study by Wixom and Watson (2001) emphasized accuracy, completeness, consistency and comprehensiveness and examined how these lessen the effort and time required to make decisions among end users. In contrast, data reliability is the most commonly examined aspect in auditing and accounting (e.g., Johnson et al., 1981). Lastly, in terms of marketing, the emphasis is on information quality's dimensions, such as access and integration (e.g., Jayachandran et al., 2005).

A more specific aspect of E-banking study focuses on how information quality is related to issues about system content, including timeliness, accuracy, relevance and completeness (e.g., DeLone and McLean, 2003; 2004; Ayyash, 2015).

Information accuracy refers to the level of data that is considered reliable, correct and measured in a manner that is precise (Wang and Strong, 1996). In the field of E-banking, the information systems' accuracy is related to the spelling, facts, rules and consistency of information, along with the continuity that is observed on the site. The results of regression analysis supported hypothesis (H1). This result signifies that in Palestine, information accuracy is significantly and positively related to customer satisfaction towards E-banking services $(\beta=0.256, \mathrm{p}<0.001)$. Thus, higher satisfaction towards E-banking services is related to higher information accuracy levels.

On the other hand, information timeliness is defined as the output information's availability at the right time (Bailey and Pearson, 1983). In this case, the results of the regression analysis supported the hypothesis at $(\beta=$ $0.160, p<0.062$ ). Furthermore, information completeness is used to refer to the level at which information is considered enriching based on its depth, breadth and ability to handle the required task (Bailey and Pearson, 1983). The results of the regression analysis supported the hypothesis that is related to information completeness at $(\beta=0.083, \mathrm{p}<0.283)$. Moreover, the results from the information relevancy were also found to be in support of the relationship at $(\beta=0.461$, $p<0.000)$. Thus, the results obtained from the regression analysis were also found to support the second, third and fourth hypotheses. This is indicative of the fact that in Palestine, information completeness, timeliness and relevancy are significantly and positively related to the satisfaction of customers towards E-banking services. This also signifies that higher levels of information completeness, timeliness and relevancy will result into higher satisfaction towards E-banking services.

\section{Customer Satisfaction towards E-banking Services and their Intention to Use}

Customer satisfaction is one of the top criteria for the implementation of successful information systems. Therefore, it is vital to evaluate satisfaction and its determinants in order to measure the value and efficacy of any investment towards an information system (Kassim et al., 2012). Customer satisfaction thus refers to the collection of evaluations, perceptions and psychological outcomes that are related to the consumption of experiences associated with a product/service (Saha and Zhao, 2005). Majority of banks offer e-banking as a new e-service channel that provides customers with various online services along with the added convenience of transactions and information access (Klien and Quelch, 1997; Polatoglu and Ekin, 2001). Previous studies have all agreed that E-banking services have a significant effect on customer satisfaction (e.g., Gbadeyan and Akinyosoye, 2011; Alabar, 2012; Ojokuku and Sajuyigbe, 2012; Oladejo and Akanbi, 2012).

This study's findings supported hypothesis (H5) and confirmed that in Palestine, customer satisfaction towards E-banking services is significantly and positively related to their intention to utilize the services at $(\beta=0.599, \mathrm{p}<0.000)$. This finding coincides with previous studies, such as those of Cronin and Taylor (1992; Rust and Oliver, 1994; Patterson and Spreng, 1997; Cronin et al., 2000; Tian-Cole et al., 2002). These previous studies have all proved customer satisfaction and service quality have a positive impact on the customer's perceptions and intention to purchase. It has been stated clearly that customers who are more satisfied of the E-banking services are more likely to use such services. 


\section{Conclusion, Limitations and Recommendations}

This study had five hypotheses that were related to the relationship between customer satisfaction about Ebanking services in Palestine and the dimensions of information quality. It also examined the effect of customer satisfaction on the customers' intention to utilize E-banking services within the Palestinian banking sector. Therefore, this study has major contributions to the understanding and knowledge of information quality's dimensions and how they are related to a customer's intention to use. This aspect was mostly omitted in prior studies, especially in the Palestinian context.

A multiple regression analysis was utilized by the researcher to assess the first four hypotheses. These four hypotheses proposed a relationship between customer satisfaction and the dimensions of information quality. Afterwards, a simple test was conducted to examine the relationship between the intention to use E-banking services and customer satisfaction. The findings revealed and confirmed that there was a significant and positive relationship among the dimensions of information quality, namely timeliness, completeness, accuracy and relevance and customer satisfaction. A subsequent analysis established a positive and significant relationship between the intention to use E-banking services and customer satisfaction towards E-banking services.

The study sample was made up of customers who were patrons of three Palestinian banks. Thus, further research has to be conducted in order to determine if the findings were consistent with findings from studies conducted in other countries. Specifically, the study's predictions need to be examined using cross-cultural studies that involve a larger sample size. Moreover, the results can be compared to the results of other research that had large and diversified samples in order to ensure optimum accuracy. Furthermore, given the fact that this study examined a limited number of information quality dimensions, further studies can look into incorporating additional dimensions like ease of understanding or upto-date information. These other dimensions may have a potential impact on customer satisfaction about Ebanking services not only in Palestine, but in other contexts as well. Lastly, future studies can also examine the effect of other dimensions on the satisfaction of customers with E-banking services and how that affects their intention to use the services. This allows for a more generalizable result and might provide a more in-depth understanding of the phenomenon being investigated.

\section{Ethics}

The author confirms that that there have been no ethical issues committed and that this manuscript has not been published anywhere else.

\section{References}

Aburas, R., N. Raihan and A. Hamid, 2013. Measurement models of information service quality: A study on the banking sector. Int. J. Scientific Technol. Res., 2: 74-79.

Andoh-Baidoo, F.K., M.A. Villarreal, L.C. Liu and P. Wuddah-Martey, 2010. An exploratory study to examine the success of electronic banking systems implementation in a developing nation. Int. J. Electr. Finance, 4: 221-235.

DOI: $10.1504 /$ IJEF.2010.034031

Al Haliq, H.A. and A.A. Al Muhirat, 2016. Customer satisfaction with electronic banking services in the Saudi banking sector. Asian Soc. Sci., 12: 139-139. DOI: $10.5539 /$ ass.v12n5p139

Abu-Dalbouh, H.M., 2012. Algorithm development of bidirectional agglomerative hierarchical clustering using AVL tree with visualization. Unpublished dissertation in partial fulfilment of the requirements for the degree of Doctor of Philosophy, University Sains Islam Malaysia, Bandar Baru Nilai, Negeri Sembilan, Malaysia.

Almahamid, S., A.C. McAdams, T. Alkalaldeh and M. Al-Sa'eed, 2010. The relationship between perceived usefulness, perceived ease of use, perceived information quality and intention to use E-government. J. Theoretical Applied Inform. Technol., 11: 30-44. f

Aladwani, A.M. and P.C. Palvia, 2002. Developing and validating an instrument for measuring userperceived web quality. Inform. Manage., 39: 467-476. DOI: 10.1016/S0378-7206(01)00113-6

Ayyash, M.M., K. Ahmed and D. Singh, 2012. A hybrid information system model for trust in e-government initiative adoption in public sector organization. Int. J. Bus. Inform. Syst., 11: 162-179. DOI: $10.1504 /$ IJBIS.2012.048889

Ayyash, M.M., 2015. Identifying information quality dimensions that affect customer's satisfaction of Ebanking services. J. Theoret. Applied Inform. Technol., 82: 122-130.

Ayyash, M.M., K. Ahmad and D. Singh, 2013. Investigating the effect of information systems factors on trust in E-government initiative adoption in Palestinian public sector. Res. J. Applied Sci. Eng. Technol., 5: 3865-3875.

Allen, F., J. McAndrews and P. Strahan, 2001. Efinance: An introduction. Working Paper, 01-36. Financial Institutions Center, Wharton University, Philadelphia, PA.

Alabar, T.T., 2012. Electronic banking services and customer satisfaction Nigerian banking industry. Int. J. Bus. Manage., 2: 1-8. 
Al-Tit, A.A., 2015. The effect of service and food quality on customer satisfaction and hence customer retention. Asian Soc. Sci., 11: 23, p.129.

Bailey, J.E. and S.W. Pearson, 1983. Development of a tool for measuring and analyzing computer user satisfaction. Manage., Sci., 29: 530-545.

DOI: $10.1287 / \mathrm{mnsc} .29 .5 .530$

Ballou, D., S. Madnick and R. Wang, 2003. Special section: Assuring information quality. J. Manage.. Inform. Syst., $20: 9-11$.

Baskarada, S., A. Koronios and J. Gao, 2006. Towards a capability maturity model for information quality management: a TDQM approach. Proceedings of the 11th International Conference on Information Quality, Nov. 10-12, MIT, Cambridge, Massachusetts, USA.

Buyukozkan, G., D. Ruan and O. Feyzioglu, 2007. Evaluating E-learning web site quality in a fuzzy environment. Int. J. Intell. Syst., 22: 567-586.

Buzzacchi, L., G. Massimo Colombo and M. Sergio, 1995. Technological regimes and innovation in services: The case of the Italian banking industry. Res. Policy, 24: 151-168. DOI: 10.1016/0048-7333(93)00756-J

Bauer, H.H., M. Hammerschmidt and T. Falk, 2005. Measuring the quality of E-banking portals. Int. J. Bank Market., 23: 153-175.

DOI: $10.1108 / 02652320510584395$

Carter, L. and F. Bélanger, 2005. The utilization of e government services: Citizen trust: Innovation and acceptance factors. Inform. Syst. J., 15: 5-25. DOI: $10.1111 /$ j.1365-2575.2005.00183.x

Chau, P.Y.K. and P.J.H. Hu, 2001. Information technology acceptance by individual professionals: A model comparison approach. Decis. Sci., 32: 699-719.

DOI: $10.1111 / \mathrm{j} .1540-5915.2001 . t b 00978 . x$

Chavan, J., 2013. Online banking-the advantages and challenges in the emerging economy. Int. J. Res. Bus. Manage., 1: 19-26.

Chuan-Chuan Lin, J. and H. Lu, 2000. Towards an understanding of the behavioural intention to use a web site. Int. J. Inform. Manage., 20: 197-208. DOI: $10.1016 / \mathrm{S} 0268-4012(00) 00005-0$

Cronin, J. and S. Taylor, 1992. Measuring service quality: Re-examination and extension. J. Market., 56: 55-68. DOI: $10.2307 / 1252296$

Cronin, J.J., M.K. Brady and T.M. Hult, 2000. Assessing the effects of quality, value, customer satisfaction on consumer behavioral intentions in service. $\mathrm{J}$. Market., 59: 78-94.

DOI: $10.1016 / \mathrm{S} 0022-4359(00) 00028-2$

Harrison, D.L., 2016. Understanding the impact of information quality on customer relationship management. Doctor of Business Administration Dissertations. Kennesaw, GA.
Davis, L. and B. Jackson, 2005. Acquiring, Implementing and Evaluating Information Technology. In: Information Technology and the Criminal Justice System, Pattavina, A. (Ed.), SAGE, Thousand Oaks, ISBN-10: 0761930191, pp: 29-57.

Delone, W.H. and E.R. Mclean, 1992. Information systems success: The quest for the dependent variable. Inform. Syst. Res., 3: 60-95.

DOI: $10.1287 /$ isre.3.1.60

Delone, W.H. and E.R. Mclean, 2003. The DeLone and McLean model of information systems success: A ten-year update. J. Manage. Inform. Syst., 19: 9-30.

Delone, W.H. and E.R. Mclean, 2004. Measuring ecommerce success: Applying the DeLone and McLean information systems success model. Int. J. Elect. Commerce, 9: 31-47.

Dedeke, A., 2000. A conceptual framework for developing quality measures for information systems. Proceeding of the 5th International Conference on Information Quality, (CIQ' 00), pp: 126-128.

David, G., B. Pierre and L. Darren, 2004. Barriers and benefits in the adoption of E-government. Int. J. Pub. Sect. Manage., 17: 286-301. DOI: $10.1108 / 09513550410539794$

Dewan, R., M. Freimer and A. Seidmann, 2000. Organizing distribution channels for information goods on the Internet. Manage. Sci., 46: 483-496. DOI: $10.1287 / \mathrm{mnsc}$.46.4.483.12053

Eppler, M. and P. Muenzenmayer, 2002. Measuring information quality in the web context: A survey of state-of-the-art instruments and an application methodology. Proceedings of 7 th International Conference on Information Quality, (CIQ' 02), pp: 187-196.

Friedman, T., S. Nelson and J. Radcliffe, 2004. CRM demands data cleansing. Gartner Research.

Gbadeyan, R.A and O.O. Akinyosoye, 2011. Customers' preference for e-banking services: A case study of selected banks in Sierra Leon. Austral. J. Bus. Manage. Res., 1: 108-116.

Hussein, R., N.S.A. Karim, N. Mohamed and A.R. Ahlan, 2007. The influence of organizational factors on information systems success in E-government agencies in Malaysia. Electr. J. Inform. Syst. Dev. Countries, 29: 1-17.

Hussein, S.A., 2009. An empirical investigation of information systems success: An analysis of the factors affecting banking information systems success in Egypt. PhD Thesis, University of Bradford.

Jayachandran, S., S. Sharma, P. Kaufman and P. Raman, 2005. The role of relational information processes and technology use in customer relationship management. J. Market., 69: 177-192.

DOI: $10.1509 / j m k g .2005 .69 .4 .177$ 
Johnson, J.R., R.A. Leitch and J. Neter, 1981. Characteristics of errors in accounts receivable and inventory audits. Account. Rev., 56: 270-293.

Jovovic, R., E. Lekic and M. Jovovic, 2016. Monitoring the quality of services in electronic banking. J. Central. Bank. Theory Pract., 5: 99-119. DOI: $10.1515 /$ jcbtp-2016-0022

Jennex, M., L. Olfman., P. Panthawi and Y.T Park, 1998. An organizational memory information systems success model: An extension of DeLone and McLean's I/S success model. Proceedings of the 31th Annual Hawaii International Conference on System Sciences, Jan. 06-09, IEEE Xplore Press, Hawaii, USA., pp: 157-165. DOI: 10.1109/HICSS.1998.653096

Kahn, B.K, D.M. Strong and R.Y Wang, 2002. Information quality benchmarks: Product and service performance. Comm. ACM, 45: 184-192. DOI: $10.1145 / 505248.506007$

Khayun, V., P. Ractham and D. Firpo, 2012. Assessing e-excise success with Delone and Mclean's model. J. Comput. Inform. Syst., 52: 31-40. DOI: $10.1080 / 08874417.2012 .11645556$

Knox, M., 2004. Banks and asset managers are enhancing data quality. Gartner Research.

Kassim, E.S., S.F.A.K. Jailani, H. Hairuddin and N.H. Zamzuri, 2012. Information system acceptance and user satisfaction: The mediating role of trust. Proc. Soc. Behav. Sci., 57: 412-418. DOI: $10.1016 /$ J.SBSPRO.2012.09.1205

Kim, M. and S. Lennon, 2008. The effects of visual and verbal information on attitudes and purchase intentions in internet shopping. Psychol. Market, 25: 146-178. DOI: 10.1002/mar.20204

Klien, L.R. and J.A. Quelch, 1997. Business-to-Business market making on the Internet. Int. Market. Rev., 14: 345-361. DOI: 10.1108/02651339710367647

Katerattanakul, P. and K. Siau, 1999. Measuring information quality of web sites: Development of an Instrument. Proceedings of the 20th International Conference on Information Systems, Dec. 12-15, Association for Information Systems Atlanta, Charlotte, North Carolina, pp. 279-286.

Leung, H.K.N., 2001. Quality metrics for intranet applications. Inform. Manage., 38: 137-152. DOI: $10.1016 / \mathrm{S} 0378-7206(00) 00060-4$

Logan, D. and D. Newman, 2006. Gartner introduces the EIM maturity model. Gartner Research.

Lee, S., E. Park., S.J. Kwon and A.P. del Pobil, 2015. Antecedents of behavioral intention to use mobile telecommunication services: Effects of corporate social responsibility and technology acceptance. Sustainability, 7: 11345-11359.

DOI: $10.3390 /$ su70811345
Lee, Y.W., D.M. Strong, B.K. Kahn and R.Y. Wang, 2002. AIMQ: A methodology for information quality assessment. Inform. Manage., 40: 133-146. DOI: 10.1016/S0378-7206(02)00043-5

Ling, G.M., Y.S. Fern., L.K. Boon and T.S. Huat, 2016. Understanding customer satisfaction of internet banking: A case study in Malacca. Proc. Econom. Finance, 37: $\quad 80-85$. DOI: $10.1016 / \mathrm{S} 2212$ 5671(16)30096-X

Maes, A. and G. Poels, 2006. Evaluating quality of conceptual models based on user perceptions. Proceedings of teh International Conference on Conceptual Modeling, Nov. 6-9, Springer, Berlin, Germany, pp: 54-67.

Munir, M.M.M., 2015. E-banking service quality and customer satisfaction of a state owned schedule bank of Bangladesh. J. Int. Bank. Commerce.

Molla, A. and P.S. Licker, 2001. E-commerce systems success: An attempt to extend and respecify the delone and McLean model of ISS. J. Elect. Commerce Res., 2: 131-141.

Manchanda, A. and S. Mukherjee, 2014. An empirical application of DeLone and McLean model in evaluating decision support system in the banking sector of Oman. J. Int. Technol. Inform. Manage.

Mashhour, A., 2008. A framework for evaluating the effectiveness of information systems at Jordan banks: An empirical study. J. Int. Bank. Comm, 13: 1-14. DOI: 10.1016/S2212-5671(16)30096-X

Nupur, J.M., 2010. E-banking and customers' satisfaction in Bangladesh: An analysis. Int. Rev. Bus. Res., 6: 145-156.

Nurse, J.R., S.S. Rahman., S. Creese., M. Goldsmith and K. Lamberts, 2011. Information quality and trustworthiness: A topical state-of-the-art review. Proceedings of the International Conference on Computer Applications and Network Security, (ANS' 11).

Negasha, S., T. Ryanb and M. Igbaria, 2003. Quality and effectiveness in Web-based customer support systems. Inform. Manage., 40: 757-768. DOI: 10.1016/S0378-7206(02)00101-5

Naumann, F. and C. Rolker, 2000. Assessment methods for information quality criteria. Proceedings of 5 th International Conference on Information Quality, (CIQ’ 00), pp: 148-162.

Okechi, O. and O.M. Kepeghom, 2013. Empirical evaluation of customers' use of electronic banking systems in Nigeria. African J. Comput. ICT, 6: 7-20.

Olatokun, W. and O.J. Owoeye, 2012. Influence of individual, organizational and system factors on attitude of online banking users. Proceedings of Informing Science and IT Education Conference, (ITEC' 12), pp: 389-406. 
Oladejo, $\mathrm{M}$ and T. Akanbi, 2012. Banker's perceptions of electronic banking in Nigeria: A review of post consolidation experience. Res. J. Fina. Account., 3: 1-11.

Ojokuku, R.M. and A.S. Sajuyigbe, 2012. The Impact of electronic banking on human resources performance in the Nigerian banking industry. Int. J. Econ. Dev. Res. Invest., 3: 61-69.

O'Reilly, C.A., 1982. Variations in decision makers' use of information sources: The impact of quality and accessibility of information. Acad. Manage. J., 25: 756-771.

Polatoglu, V.N and S. Ekin, 2001. An empirical investigation of the Turkish consumer's acceptance of internet banking services. Int. J. Bank. Market., 19: 156-165. DOI: 10.1108/02652320110392527

Patterson, P.G. and R.A. Spreng, 1997. Modeling the relationship between perceived value, satisfaction and repurchase intentions in a business-business, services context: An empirical examination. Int. J. of Serv. Indu. Manag, 8:5, pp. 414-418.

Ramayah, T., N.H. Ahmad and M.C. Lo, 2010. The role of quality factors in intention to continue using an elearning system in Malaysia. Proc. Soc. Behav. Sci., 2: 5422-5426. DOI: 10.1016/j.sbspro.2010.03.885

Rai, A., S.S. Lang and R.B Welker, 2002. Assessing the validity of IS success models: An empirical test and theoretical analysis. Info. Syst. Res., 13: 50-50. DOI: $10.1287 /$ isre.13.1.50.96

Romi, I.M., 2013. Testing Delone and Mclean's model in financial institutions. Am. Acad. Scholarly Res. J., 5: 121-129.

Ramdan, S.M.A., Y.N.B. Azizan and K.B Saadan, 2014. E-government systems success evaluating under principle Islam: A validation of the Debone and McLean model of Islamic information systems success. Acad. Res. Int., 5: 72-85.

Rust, R.T. and R.L. Oliver, 1994. Insights and Managerial Implications from the Frontier. In: Service Quality: New Directions in Theory and Practice, Rust, R.T. and R.L. Oliver (Eds.), Sage, Thousand Oaks, CA., pp: 1-19.

Sang, S. and J.D. Lee, 2009. A conceptual model of egovernment acceptance in public sector. Proceedings of the 3rd International Conference on Digital Society, Feb. 1-7, IEEE Xplore Press, pp: 71-76. DOI: 10.1109/ICDS.2009.30

Saleem, Z. and K. Rashid, 2011. Relationship between customer satisfaction and mobile banking adoption in Pakistan. Int. J. Trade. Econ. Finance, 2: 537-537.

Stvilia, B., M.B. Twidale, L.C. Smith and L. Gasser, 2005. Assessing information quality of a community-based encyclopaedia. Proceedings of the International Conference on Information Quality, (CIQ’ 05), Cambridge, MA, 442-454.
Shanks, G and B. Corbitt, 1999. Understanding data quality: Social and cultural aspects. Proceedings of the 10th Australasian Conference on Information Systems, (CIS' 999).

Saha, P. and Y. Zhao, 2005. Relationship between online service quality and customer satisfaction, a study in Internet banking. Lulea University.

Setia, P., V. Venkatesh and S. Joglekar, 2013. Leveraging digital technologies: How information quality leads to localized capabilities and customer service performance. MIS Q., 37: 565-590.

Seddon, P.B. and K. Min-Yen, 1994. A partial test and development of the Delone and Mclean model of is success. Proceedings of the International Conference on Information System, (CIS’ 94), pp: 99-110.

Stamoulis, D., P. Kanellis and D. Martakos, 2002. An approach and model for assessing the business value of e-banking distribution channels: Evaluation as communication. Int. J. Inform. Manage., 22: 247-261. DOI: $10.1016 / \mathrm{S} 0268-4012(02) 00011-7$

$\mathrm{Su}, \mathrm{Y}$. and Z. Jin, 2006. A methodology for information quality assessment in the designing and manufacturing process of mechanical products. Inf. Qua. Manag.: Theo. and App., pp.190-220.

Tarhini, A., T. Teo and T. Tarhini, 2016. A cross-cultural validity of the E-learning Acceptance Measure (ElAM) in Lebanon and England: A confirmatory factor analysis. Educ. Inform. Technol., 21: 1269-1282. DOI: $10.1007 / \mathrm{s} 10639-015-9381-9$

Truch, E., 2006. Lean consumption and its influence on brand. J. Consumer Behav., 5: 157-165.

DOI: $10.1002 / \mathrm{cb} .42$

Tian-Cole, S.T., J.K. Crompton and V.L. Willson, 2002. An empirical investigation of the relationships between service quality, satisfaction and behavioral intentions among visitors to a wildlife refuge. J. Leisure Res., 34: 1-24.

Unyathanakorn, K. and N. Rompho, 2014. Factors affecting customer satisfaction in online banking service. J. Market. Dev. Competitiveness, 8: 50-50.

Venkatesh, V., M.G. Morris., G.B. Davis and F.D. Davis, 2003. User acceptance of information technology: Toward a unified view. MIS. Q., 27: 425-478.

Vanniarajan, T.A., 2009. Management information systems for service quality in commercial banks: An empirical study. Asia Pacific Bus. Rev., 5: 61-74. DOI: 10.1177/097324700900500205

Wang, J.S. and T.S Pho, 2009. Drivers of customer intention to use online banking: An empirical study in Vietnam. African J. Bus. Manage., 3: 669-669.

Wangpipatwong, S., W. Chutimaskul and B. Papasratorn, 2005. Factors influencing the adoption of Thai e-government websites: Information quality and system quality approach. Proceedings of the 4th International Conference on eBusiness, Nov. 19-20, Bangkok, Thailand, pp: 14.1-14.7. 
Wang, Y.S. and Y.W Liao, 2008. Assessing eGovernment systems success: A validation of the DeLone and McLean model of information systems success. Gover.. Inform. Q., 25: 717-733.

DOI: $10.1016 /$ j.giq.2007.06.002

Wang, R.Y and D.M. Strong, 1996. Beyond accuracy: What data quality means to data consumers. J. Manage. Inform. Syst., 12: 5-33.

DOI: $10.1080 / 07421222.1996 .11518099$

Wungwanitchakorn, A., 2002. Adoption intention of banks' customers on internet banking service. ABAC J., 22: 63-80.

Wixom, B.H. and H.J. Watson, 2001. An empirical investigation of the factors affecting data warehousing success. MIS Q., 25: 17-41.

DOI: $10.2307 / 3250957$
Wixom, B.H. and P.A. Todd, 2005. A theoretical integration of user satisfaction and technology acceptance. Inform. Syst. Res., 16: 85-102. DOI: $10.1287 /$ isre. 1050.0042

Yoon, Y., T. Guimaraes and Q. O’Neal, 1995. Exploring the factors associated with expert systems success. MIS. Q., 19: 83-106. DOI: 10.2307/249712

Zhu, J.D.S. and C.T Lin, 2010. The antecedents and consequences of e-service quality for online banking. Soc. Behav. Personality, 38: 1009-1018. DOI: $10.2224 / \mathrm{sbp} .2010 .38 .8 .1009$ 